\title{
Insulin Preparations with Prolonged Effect
}

\author{
David R. Owens, C.B.E., M.D., F.R.C.P., F.I.Biol.
}

\begin{abstract}
The discovery of insulin and its clinical application early in the last century dramatically improved the prospects of people with diabetes. However, the limitations of those initial, unmodified insulin preparations were quickly recognized; most notably, their relatively "short action" meant that multiple daily subcutaneous injections were required. This stimulated a concerted effort to modify the properties of insulin in order to extend the duration of its blood glucose-lowering effect, minimize dosing frequency, and decrease the burden of treatment. The first successful attempts to prolong insulin's action were achieved by modifying its formulation with additives such as protamine and zinc, culminating in the production of "intermediate-acting" neutral protamine Hagedorn (NPH) insulin in the 1940s and the lente family of insulins in the 1950s. However, NPH and lente insulins were still associated with several limitations, including considerable variability of effect and a pronounced peak in their time-action profile. In the 1980s, the focus of research moved toward the modification of insulin itself with the aim of producing a "long-acting" insulin that would better satisfy basal insulin requirements over the entire day. Once-daily insulin glargine was the first "long-acting" insulin analog in clinical practice, followed by onceor twice-daily insulin detemir and, more recently, insulin degludec, which is now being evaluated for administration at less frequent intervals. These analogs demonstrate several benefits over "intermediate-acting" insulins, including a lower risk of both overall hypoglycemia and nocturnal hypoglycemia and reduced dayto-day glucose variability, making it more feasible to achieve better fasting and overall glycemic control. Longacting insulin analogs (insulin glargine and insulin detemir) are now firmly established as key tools in the battle against diabetes, and ongoing clinical research of insulin-based therapy should focus on treatment strategies to maximize their benefits. To date, the clinical experience with insulin degludec is limited but demonstrates it has comparable efficacy to insulin glargine.
\end{abstract}

\section{Introduction}

$\mathbf{T}$ HE FIRST WRITTEN REFERENCE to a diabetes-like syndrome dates back to approximately 1,500 BC in ancient Egypt, but it was only early in the last century that effective intervention to manage the symptoms of diabetes became a reality. The connection between diabetes and the pancreas was first made late in the $19^{\text {th }}$ century, following which the search for the active principle from the islets of Langerhans began in earnest. Early in the $20^{\text {th }}$ century, several research groups in Europe (e.g., Zuelzer, and Paulesco) and North America (e.g., Scott, Kleiner, Murlin, and Kramer) observed encouraging results, eventually culminating in the isolation of insulin in 1922 by Banting and Best. ${ }^{1}$ Soon afterward, insulin therapy was introduced for the treatment of diabetes ${ }^{2}$ with dramatic results. At first, the only preparation available was a relatively "short-acting," acid solution of an impure, unmodified form of insulin, requiring multiple daily subcutaneous injections and often resulting in local reactions at the site of the injection. This prompted research into the production of a more pure insulin preparation with a prolonged subcutaneous absorption, with the intention of extending the duration of hypoglycemic effect and thereby minimize the number of daily injections required. This article summarizes the historical development of conventional long-acting insulins and longacting insulin analogs and explores how these agents have become established in the management of diabetes in recent years.

\section{Prolonging Insulin Action-The Early Years}

Initial attempts to prolong the action of insulin involved combining it with gum arabic solutions, ${ }^{3}$ oil suspensions, ${ }^{4}$ lecithin emulsions, ${ }^{5}$ or vasoconstrictor substances, ${ }^{6}$ none of which was very successful. ${ }^{7,8}$ In 1935 , the research groups of Maxwell and Bischoff ${ }^{9}$ and Scott and Fisher ${ }^{10}$ reported that the addition of certain metal ions, such as zinc, prolonged insulin activity. The following year, the use of strongly basic proteins (protamines) combined with neutral suspensions of insulin was also shown to delay absorption from a

Diabetes Research Unit, Cardiff University, University Hospital Llandough, Penarth, United Kingdom. 
subcutaneous depot. ${ }^{11}$ During 1936, Hans Christian Hagedorn and colleagues produced the first clinically useful protracted, "intermediate-acting" insulin in the form of a neutral suspension of protamine insulin, ${ }^{12}$ although this was found to be chemically unstable. A further preparation using excess protamine and a small amount of zinc, ${ }^{13}$ known as protamine zinc insulin (PZI), achieved a prolonged hypoglycemic effect of up to 24 h. ${ }^{14,15}$ However, PZI was limited by a greater risk of hypoglycemia, with reports of sudden and severe attacks. ${ }^{15}$ In addition, the onset of action of PZI was slow (1-3h) and required the addition of soluble insulin to achieve an intermediate action, ${ }^{16-18}$ but this admixture was shown to be unstable $^{19}$ and had to be administered as separate injections, causing inconvenience to patients. Finally, in 1946, Hagedorn and colleagues introduced crystalline neutral protamine Hagedorn (NPH) insulin, which was a more stable PZI modification combining insulin and protamine in "isophane" proportions (no excess of insulin or protamine) at neutral $\mathrm{pH}$ in the presence of a small amount of zinc and phenol and/or phenol derivatives to generate tetragonal oblong-shaped crystals. ${ }^{20}$ Unlike PZI, the NPH insulin preparation could be premixed with an intermediate-acting insulin and quickly became, and has since remained, popular as a once- or twicedaily insulin, used alone or in combination with soluble insulin as required. ${ }^{21}$

Research and development continued to advance, and other insulin preparations were introduced in an attempt to address the continued need for long-acting agents with a better time-action profile. In the 1930s, globin insulin was developed, ${ }^{22,23}$ as well as surfen insulin, which was formulated with a synthetically produced urea as an alternative to protamine. $^{24}$ Then in the 1950s, the lente trilogy of insulins, comprising semilente, lente, and ultralente, were developed by Hallas-Mǿller ${ }^{25}$ and colleagues. These were protracted insulin preparations, without any added foreign proteins or synthetic compounds, created by complexing neutral suspensions of insulin with small amounts of zinc ions. The duration of action of members of the lente family of insulins was determined by the physical state, size, and zinc content of the suspended zinc insulin particles.

Traditionally, insulin was extracted from porcine and/or bovine pancreata, which have different solubilities at neutral $\mathrm{pH}$. Insulins of the lente type capitalized on this to achieve different protracted activity. The original lente insulin preparation comprised a 3:7 mixture of amorphous porcine insulin and bovine crystalline particles, with an intermediate timing of action similar to that of NPH insulin. ${ }^{26,27}$ Bovine ultralente insulin comprised fairly large crystals $(30 \mu \mathrm{m})$ resulting in a duration of action similar to PZI. Ultralente is considered to be the first real "long-acting" insulin preparation, requiring concomitant administration with preprandial insulin in subjects with type 1 diabetes and late in the natural history of type 2 diabetes. Additionally, lente-type preparations such as Monotard $^{\circledR}$ (Novo Nordisk, Bagsvaerd, Denmark) and Rapi$\operatorname{tard}^{\circledR}$ (Novo Nordisk), comprising 100\% porcine insulin and $25 \%$ porcine $/ 75 \%$ bovine crystalline insulin, respectively, were later produced. ${ }^{28-30}$ Throughout this period, considerable efforts were also being made to better purify the various insulin preparations.

During the 1980s, commercial production of human insulin began, initially derived semisynthetically from porcine insulin using an enzymatic process ${ }^{31}$ and later biosynthetically using Escherichia coli or yeast (Saccharomyces cerevisiae). ${ }^{32,33}$ Subsequently, NPH, lente, ultralente, and premixed preparations were reformulated using human insulin. However, evidence revealed that long-acting human insulin had a shorter duration of action than the animal equivalent. For example, the human insulin version of ultralente (Ultratard ${ }^{\circledR}$ $\mathrm{HM}$ ) is absorbed much more quickly than its bovine counterpart (Ultratard MC) (both from Novo Nordisk). ${ }^{34,35}$ The development of ultralente HM, therefore, deviated from the ideal slowly absorbed preparation that is required to mimic the pattern of basal insulin secretion in people without diabetes. Insulin formulations based on crystalline suspensions, including the lente-type insulins and NPH, are also limited by the need for resuspension. The variability of response seen with these insulins may be a result of a failure to evenly resuspend the insulin within the vial immediately prior to administration. The development and evaluation of biosynthetic human proinsulin, the precursor of endogenous insulin, as a long-acting insulin achieved a significant reduction in variability of effect relative to NPH insulin, while demonstrating a similarly prolonged hypoglycemic action. ${ }^{36}$ However, the failure of human proinsulin to demonstrate efficacy benefits over NPH, together with evidence, although not conclusive, of cardiac adverse events led to the termination of its development for clinical use. ${ }^{36}$

Exogenous insulin may also be limited by its distribution in the body. Endogenous insulin is secreted from the pancreas into the hepatic portal vein, such that the liver is subjected to relatively high insulin concentrations and is responsible for uptake of as much as $60 \%$ of the pancreatic output. When exogenous insulin is delivered subcutaneously, its distribution is more even throughout the body, and the liver may be relatively underinsulinized. Hepatoselective exogenous insulin was generated in the 1990s by covalently linking a thyroxyl group to the insulin molecule. The resulting thyroxyl-insulin analog binds to thyroid hormone binding proteins to form complexes with a molecular size that limits access to the peripheral tissues because of the capillary endothelial barrier, but is more readily accessible to the liver hepatocytes because of the greater permeability of the sinusoid vessels. Small-scale, clinical studies showed that thyroxyl-insulin had an inhibitory effect on hepatic glucose production that was comparable to the value for NPH insulin, but the effect on peripheral glucose uptake was significantly lower than for NPH. ${ }^{37}$ Utilization of insulin analog techniques ("designer insulins") has subsequently been influential in the development of pharmacokinetically optimized insulins for clinical practice.

\section{Retarding Insulin Absorption Through Targeted Structural Modification: The Insulin Analogs}

Short- and intermediate-acting insulins have important roles to play in the overall management of diabetes, but the availability of long-acting insulin preparations, effective over a period of $24 \mathrm{~h}$, is better suited to maintain physiological basal insulin levels (Table 1). The advent of recombinant DNA technology enabled researchers to begin to modify the structural properties of insulin with the subsequent introduction of human insulin and later insulin analogs in an attempt to optimize their physicochemical characteristics to better simulate insulin secretory patterns. 
Table 1. Main Types of Insulin Preparations

\begin{tabular}{|c|c|c|c|c|}
\hline Type & Onset & Peak & Duration & Comments \\
\hline Rapid-acting insulin analog & $5-15 \min$ & $30-60 \mathrm{~min}$ & $2-5 \mathrm{~h}$ & Can be injected at the start of a meal \\
\hline $\begin{array}{l}\text { Short-acting insulin } \\
\text { (soluble/regular insulin) }\end{array}$ & $30 \mathrm{~min}$ & $1-3 \mathrm{~h}$ & $4-8 \mathrm{~h}$ & $\begin{array}{l}\text { Usually injected } 15-30 \mathrm{~min} \text { before } \\
\text { a meal. Clear solution }\end{array}$ \\
\hline $\begin{array}{l}\text { Intermediate or long-acting } \\
\text { insulin (isophane } \\
\text { or zinc insulin) }\end{array}$ & $\begin{array}{l}\text { 1-2 h (NPH, lente) } \\
\text { 2-3 h (ultralente) }\end{array}$ & $\begin{array}{l}4-8 h \\
4-8 h\end{array}$ & $\begin{array}{l}\text { 8-12h (NPH) } \\
8-24 \text { h (ultralente) }\end{array}$ & $\begin{array}{l}\text { Used to control glucose levels } \\
\text { between meals. May be combined } \\
\text { with short-acting insulin }\end{array}$ \\
\hline Long-acting insulin analog & $30-60 \mathrm{~min}$ & No peak & $16-24 \mathrm{~h}$ & Usually taken once daily \\
\hline
\end{tabular}

$\mathrm{NPH}$, neutral protamine Hagedorn.

Early long-acting human insulin analogs were created through the addition of a positive charges, either by removal of carboxylate anions or by substituting with lysine or arginine using single-chain insulin precursors. ${ }^{38,39}$ As a result, the isoelectric point of the insulin was increased from 5.4 toward neutrality. Some of these insulin derivatives crystallize instantly when the $\mathrm{pH}$ of their slightly acidic solution is adjusted to neutral $\mathrm{pH}$ and thus becoming less soluble at the physiological $\mathrm{pH}$ of the subcutaneous tissue. Substitution with basic amino acids at the C-terminus of the B chain promotes crystallization, possibly by promoting faster interaction between hexamers, thereby ultimately slowing absorption because of the delayed disassociation of the insulin molecules from the hexameric state.

Studies continued in the 1980s involving several human insulin analogs, which constituted various amino acid substitutions, found that, of those tested, the $\mathrm{Gln}^{\mathrm{B} 13}$, $\mathrm{Arg}^{\mathrm{B} 27}$, $\mathrm{Thr}^{\mathrm{B} 30}-\mathrm{NH}_{2}$ analog had the slowest rate of dissolution at the subcutaneous injection site. ${ }^{39}$ It was subsequently found that an additional substitution at residue A21 with glycine conferred improved chemical stability during storage of the slightly acid analog solutions. ${ }^{38}$ The resorption of the ${ }^{125} \mathrm{I}-$ labeled $\mathrm{Gly}^{\mathrm{A} 21}$, $\mathrm{Arg}^{\mathrm{B} 27}$, $\mathrm{Thr}^{\mathrm{B} 30}-\mathrm{NH}_{2}$ human insulin analog (OPID 174) following subcutaneous bolus injection in individuals with type 1 diabetes demonstrated a slower and more consistent rate of dispersal compared with the human ultralente preparation. ${ }^{40}$ However, this insulin analog was not introduced into practice because of the need for escalating doses during clinical trials of NPH. ${ }^{41}$ Di-arginine insulin was also evaluated but compared poorly with NPH insulin.

\section{Currently Available Long-Acting Insulin Analogs}

\section{Insulin glargine}

In 2000, insulin glargine (glargine) became the first longacting insulin analog to be introduced into clinical practice. Glargine is an analog of human insulin produced by recombinant DNA technology whereby the insulin molecule has undergone two modifications: elongation of the C-terminus of the $\mathrm{B}$ chain with the addition of two arginine residues inserted at position B30 and replacement of asparagine with glycine at position A21 (Fig. 1A). ${ }^{42}$ The latter modification provides greater stability in the acidic $\mathrm{pH}$ of the insulin vial and makes insulin glargine less soluble at neutral $\mathrm{pH}$. As a result, glargine generates an amorphous precipitate in the subcutaneous tissue following injection, retarding its absorption and thereby extending its duration of action. ${ }^{43}$
Glargine represents a new era in protein engineering, ${ }^{44}$ with one amino acid exchange at A21; otherwise it is produced in the same process as human insulin followed by the di-arginine addition step. Insulin glargine represents the first example of a "pro-drug" protein. ${ }^{45}$ Insulin glargine itself is active and therefore not truly a prodrug but is needed for precipitation in the subcutaneous tissue. Following injection, glargine undergoes rapid sequential cleavage of the C-terminus of the B chain, forming active metabolites in the subcutaneous tissue. ${ }^{46}$ This reflects the process of degradation of proinsulin to insulin in the pancreatic $\beta$-cell. A study in healthy volunteers has demonstrated that enzymatic cleavage/maturation of glargine occurs very quickly at the injection site and continues within the circulatory system with the dissociation of the di-arginine molecules to provide fully potent insulin metabolites. ${ }^{46}$ When administered on a once-a-day basis, a steady-state condition is achieved within a few days, with no further accumulation in plasma insulin levels. ${ }^{47,48}$

The primary rationale behind the development of glargine was to avoid the poor reproducibility and pronounced peak action profile of NPH, while also providing a longer duration of action to better cover the basal insulin requirements over the entire day (Fig. 2). ${ }^{49-51}$ Glargine demonstrated a nearly flat time-action profile and reduced variability compared with $\mathrm{NPH},{ }^{49,52}$ with an end of action time of up to $24 \mathrm{~h}$, which is dose dependent and also longer acting than $\mathrm{NPH}$ insulin in individuals with type 1 diabetes. ${ }^{4-50,53,54}$ The absence of a clear peak explains the lower risk for nocturnal hypoglycemia and therefore the ability to better dose-titrate in order to achieve lower fasting blood glucose levels in both type 1 and type 2 diabetes. ${ }^{44}$ The soluble pharmaceutical formulation of glargine explains the lower variability in both the pharmacokinetics and pharmacodynamics compared with $\mathrm{NPH}^{55}$ or ultralente insulin, ${ }^{56}$ as the latter insulins require homogenization by shaking prior to injection. This finding has been confirmed in a clinical study of people with type 1 diabetes. ${ }^{57}$

The most convincing evidence for the suitability of glargine to act as a basal insulin derives from studies that compared once-daily glargine in a multiple daily injection regimen with continuous subcutaneous insulin infusion (CSII). ${ }^{58-61} \mathrm{No}$ differences were found between the two regimens regarding the level of glycemic control (A1C) achieved or the frequency of hypoglycemia. In the study by Bolli et al., ${ }^{62}$ there was also no difference in plasma glucose variability between the two regimens. The key differences between the two methods included the greater cost $(\sim 3.9$ times $)$ of CSII compared with a 
A

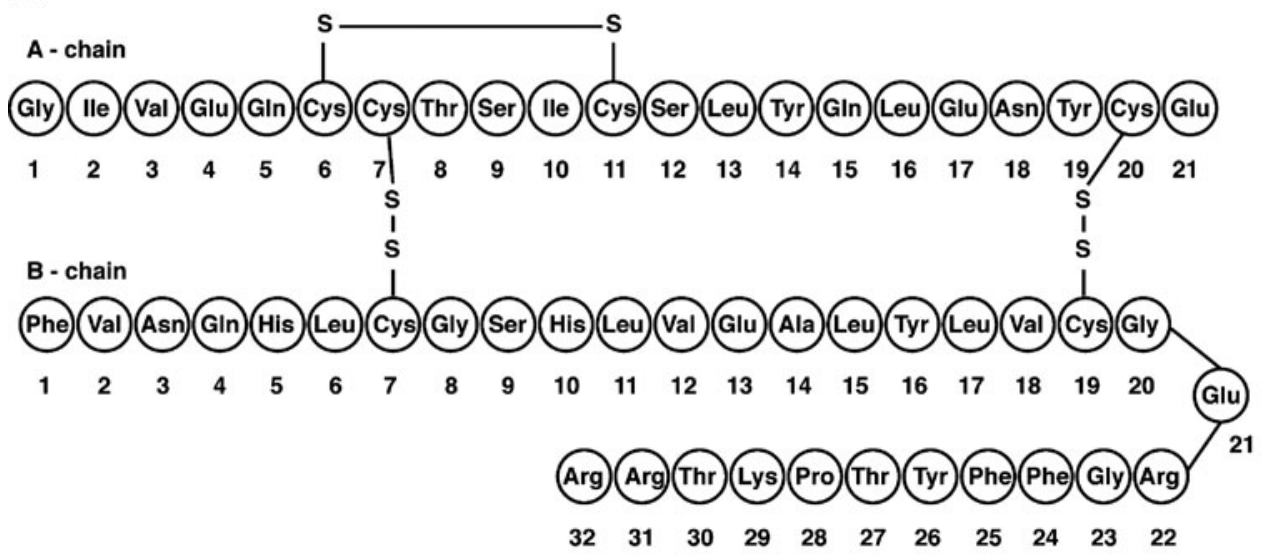

B
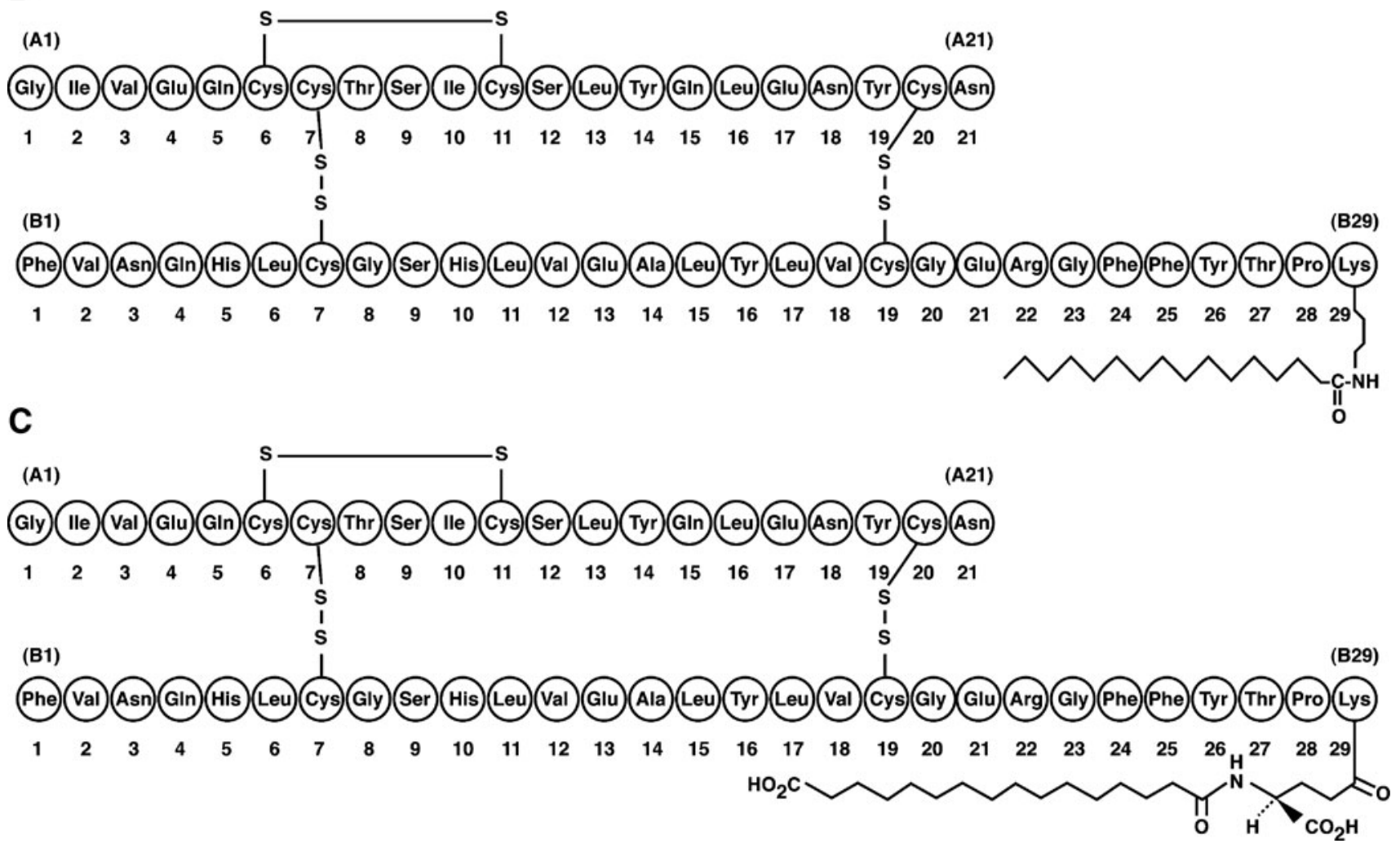

FIG. 1. Molecular structure of long-acting insulin analogs: (A) insulin glargine, (B) insulin detemir, and (C) insulin degludec.

glargine-based regimen of multiple daily injections, despite the lower $(\sim 20 \%)$ insulin dose used in the pump. ${ }^{61}$

The physicochemical properties of glargine relate to its safety profile. In vivo, glargine is rapidly cleaved into its active metabolites, which behave similarly to human insulin and thus have a low risk of adverse events related to binding at the insulin growth factor (IGF)-1 receptor, in contrast to what has been observed in vitro when using the parent compound, glargine. ${ }^{63,64}$ Clinically, no adverse outcomes have been observed with glargine with respect to microangiopathy, with no higher risk of early worsening of diabetic retinopathy with glargine compared with NPH over and above what may be related to improved glycemic control. ${ }^{65}$
More recently, a 5-year, prospective, open-label, multicenter study was conducted in a large number of people with type 2 diabetes comparing the progression of diabetic retinopathy in the NPH- and glargine-treated groups. ${ }^{66} \mathrm{NPH}$ was administered once or twice a day, whereas glargine was administered once daily with regular insulin introduced as needed. The level of glycemic control was similar at baseline in the two groups, with $\mathrm{A} 1 \mathrm{C}$ and fasting plasma glucose (FPG) values for $\mathrm{NPH}$ and glargine of $8.3 \%$ versus $8.4 \%$ and $10.0 \mathrm{mmol} / \mathrm{L}$ versus $10.5 \mathrm{mmol} / \mathrm{L}$, respectively. Seven-field fundus photographs taken at screening and at 3, 6, 12, 24, 36, 48 , and 60 months of treatment were graded according to the Early Treatment Diabetic Retinopathy Study scale, with a 


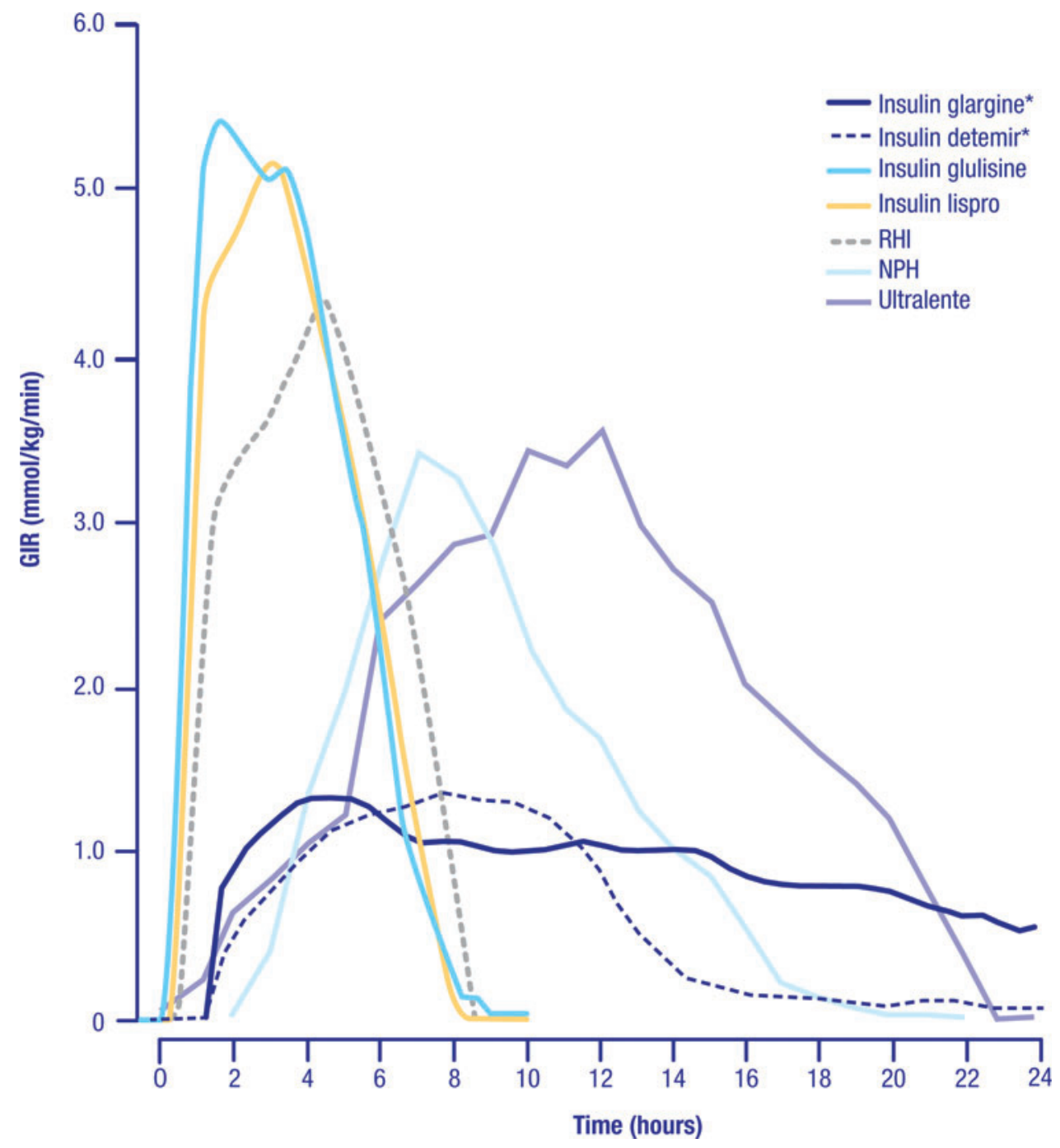

FIG. 2. Cross-study comparison of insulin time-action profiles. Data are summarized from Lepore et al., ${ }^{49}$ Porcellati et al., and Becker et al. ${ }^{51}$ All insulins were dosed at $0.3 \mathrm{U} / \mathrm{kg}\left({ }^{*}\right.$ a dose of $0.35 \mathrm{U} / \mathrm{kg}$ was used). All data are for patients with type 1 diabetes with the exception of glulisine, lispro, and regular human insulin (RHI), which are for obese healthy volunteers. GIR, glucose infusion rate; NPH, neutral protamine Hagedorn.

three-step or more change regarded as progression. The prevalence of diabetic retinopathy at baseline was $12.1 \%$ versus $15.6 \%$ for NPH and glargine insulin, respectively. At study end, both groups achieved a mean FPG level of 7.7 $\mathrm{mmol} / \mathrm{L}$ with the A1C $0.21 \%$ higher in the NPH-treated group. A three-step or more progression in the Early Treatment Diabetic Retinopathy Study score was not significantly different (i.e., $15.7 \%$ versus $14.2 \%$ in the NPH- and glarginetreated groups, respectively). Thus, in this long-term study, glargine posed no additional independent risk of progression of diabetic retinopathy compared with NPH.

Overall, in individuals with type 1 diabetes, glargine offers lifestyle benefits, improved convenience with only once-daily administration, and flexibility as to timing of injection (morning, pre-dinner, or pre-bedtime) ${ }^{67}$ There is no requirement to eat at defined times, and a fast of up to $18 \mathrm{~h}$ can be tolerated. ${ }^{68}$ Furthermore, it has been demonstrated that subcutaneous absorption of glargine is not affected by exercise. ${ }^{69}$ In individuals with type 2 diabetes, glargine also offers improved safety (reduced risk of nocturnal hypoglycemia) and convenience (once-daily administration) when attempting to reach a target A1C level of $7 \%$ (achieved in more than $50 \%$ of subjects). ${ }^{70}$ Although the level of glycemic control achieved does not differ from that achieved with $\mathrm{NPH}_{,}^{70}$ the lower risk of hypoglycemia allows for a more aggressive dose titration and consequently a greater likelihood of reaching and maintaining a lower glycemic target value over time. Indeed, a meta-analysis of patient data from 11 randomized controlled trials comparing glargine with NPH in type 1 or type 2 diabetes populations showed that the reduction in hypoglycemia with glargine versus NPH was typically underestimated. ${ }^{71}$ Analysis of hypoglycemia in these trials did not take into account the differences in A1C levels between the glargineand NPH-treated groups, and adjustment for endpoint A1C resulted in markedly greater relative reductions in the risk of hypoglycemia with glargine versus NPH. It is important that this study also revealed that the relationship between A1C and hypoglycemia for glargine and NPH diverged at lower A1C levels such that excess risk of hypoglycemia with NPH versus glargine was greater at an $\mathrm{A} 1 \mathrm{C}$ of $7 \%$ than at $9 \%$. 


\section{Insulin detemir}

Insulin detemir (detemir) was the second basal insulin analog available for clinical use. Detemir is also produced by recombinant DNA technology, with the deletion of the amino acid threonine at position B30 of the human insulin molecule and the addition of a myristic fatty acid residue to the $\varepsilon$-amino group of the lysine residue at position B29 (Fig. 1B). ${ }^{72}$ The acylation of the insulin molecule with a fatty acid residue gives the resulting molecule a higher binding affinity to albumin in the subcutaneous, intravascular, and extracellular compartments, which delays its absorption and reduces the variability of its biological activity. ${ }^{73}$

Albumin is a multifunctional transport protein that binds reversibly to several endogenous and exogenous substances. ${ }^{74,75}$ The first hypothesis for the biochemical concept of albumin binding to protract the effect of insulin was proposed by Kurtzhals et al., ${ }^{76}$ capitalizing on the knowledge that many drugs bind to albumin and that their activity profile can therefore be altered by modifying their affinity for albumin. ${ }^{77}$ A series of insulin derivatives were produced by acylation of the insulin with fatty acids of varying carbon chain lengths and affinities for albumin to find the optimum profile. ${ }^{76}$ The binding affinity of the acylated insulin for albumin relates to the number of carbon atoms on the fatty acid chain, which, in turn, relates to the duration of action of the acylated insulins, such as detemir. ${ }^{73}$

In later studies, Kurtzhals ${ }^{78}$ proposed that albumin binding, in addition to protracting absorption, improves reproducibility of the time-action profile of acylated insulins. Furthermore, it has been proposed that delayed transcapillary transport of insulin detemir in skeletal muscle occurs primarily via a nonsaturable process, such as passive diffusion via a paracellular or transcellular route, thus delaying the time for the insulin to reach its receptor. ${ }^{79}$ Acylated insulin analogs have a much reduced affinity for the insulin receptor, necessitating increased levels of active principle to achieve equivalent biopotency with human insulin preparations. ${ }^{63}$ Detemir must therefore be administered subcutaneously at five times the concentration of other basal insulins ${ }^{80}$ and, intravenously, at approximately eight times the concentration of human recombinant insulin ${ }^{81}$ in order to provide equivalent metabolic effects. In clinical studies, higher doses of the acylated insulins are also required in order to achieve the same metabolic outcome as nonacylated insulins, such as NPH and glargine. ${ }^{82-84}$ Neverthelesss, detemir has consistently demonstrated near-equivalent glycemic control and a lower increase in body weight compared with $\mathrm{NPH}$ in type 1 and 2 diabetes at appropriate doses. ${ }^{85}$

\section{Comparing glargine and detemir}

The efficacy and safety of glargine and detemir have been compared in people with type 2 diabetes, as add-on therapy to oral antidiabetes agents. ${ }^{84}$ Rosenstock et al. ${ }^{84}$ compared glargine and detemir in a 52-week, open-label, parallel, multinational trial of 582 insulin-naïve individuals. Basal insulin was initiated once daily in the evening, with a starting dose of 12 units; detemir was used additionally in the morning if predinner plasma glucose exceeded $7.0 \mathrm{mmol} / \mathrm{L}(126 \mathrm{mg} / \mathrm{dL})$. Both detemir and glargine improved A1C (from 8.6\% at baseline to $7.2 \%$ and $7.1 \%$, respectively; difference, $0.05 \%$ [ $95 \%$ confidence interval, -0.11 to $0.21 \%]$ ), with similar FPG in both groups. Furthermore, the percentage of subjects who achieved A1C $<7.0 \%$ without experiencing hypoglycemia was also similar (33\% vs. 35\%, respectively). However, weight gain was less with detemir than with glargine in completers ( 3.0 vs. $3.9 \mathrm{~kg}$; difference, $-0.9 \mathrm{~kg}$ [95\% confidence interval, -1.6 to $-0.2 \mathrm{~kg}] ; P=0.01)$. In the detemir-treated group, $55 \%$ required a twice-daily dose of $1.0 \mathrm{U} / \mathrm{kg}$, whereas the remaining $45 \%$ only required a once-daily dose of $0.52 \mathrm{U} / \mathrm{kg}$ (overall mean daily dose of detemir was $0.78 \mathrm{U} / \mathrm{kg}$ ). In contrast, with glargine (once daily in all subjects) the mean daily dose was $0.44 \mathrm{U} / \mathrm{kg}$. This study indicates that glargine and detemir may be equivalent as basal insulins in type 2 diabetes in terms of glycemic goals (lowering of A1C and risk of hypoglycemia) but that detemir required a higher dose with twice-a-day regimen in more than $50 \%$ of the cases with slightly lower weight gain.

These early findings were confirmed in a more recent, 24week, randomized, "treat-to-target" trial comparing glargine (once daily) with detemir (twice daily) in 973 insulin-naïve individuals with type 2 diabetes inadequately controlled on oral antidiabetes drugs. Glargine achieved similar glycemic control to detemir, at significantly lower doses, but with more weight gain. ${ }^{86}$ Further studies have also shown detemir (once or twice daily) and glargine (once daily) to be similar in terms of glycemic efficacy and safety when used as part of basal-bolus regimens with short-acting insulin analogs. ${ }^{87,88}$ Although absolute weight gain is less in detemir-treated individuals compared with glargine-treated patients, ${ }^{88}$ a metaanalysis of 21 studies involving either glargine (17 trials) or detemir (three trials) and one trial comparing glargine and detemir showed that weight gain adjusted for change in A1C was not significantly different between the two analogs. ${ }^{89}$

\section{Other Long-Acting Insulin Preparations in Development}

The newest arrival to the long-acting insulin analog arena is insulin degludec, currently in Phase III development. Deglu$\mathrm{dec}$ is a soluble, basal insulin analog with a reported duration of action of over $24 \mathrm{~h}$ and the potential for a thrice-weekly dosing schedule. ${ }^{90,91}$ The molecular structure of degludec retains the human insulin amino acid sequence, apart from the deletion of $\mathrm{Thr}^{\mathrm{B} 30}$ and the addition of a 16-carbon fatty diacid attached to Lys $^{\text {B29 }}$ via a glutamic acid spacer (Fig. 1C). ${ }^{92,93}$ Under in vitro conditions that mimic the subcutaneous injection site, degludec has been shown to self-associate to form large multihexamer assemblies at physiological $\mathrm{pH} .^{92,93}$ As absorption rate is influenced by molecular size, this results in the slow release of degludec monomers and an "ultra-long" action profile in type 1 diabetes.

Results from "proof-of-concept," Phase II, 16-week, openlabel, randomized trials in both type 1 and type 2 diabetes have recently been published comparing the efficacy and safety of degludec in various formulations with that of glargine. ${ }^{94,95}$ In individuals with type 1 diabetes $(n=178)$, two strengths of degludec (600 and $900 \mu \mathrm{mol} / \mathrm{L})$ were compared with glargine $(600 \mu \mathrm{mol} / \mathrm{L})$, all in a once-daily regimen, ${ }^{94}$ and in combination with insulin aspart (aspart) at meal times. Over the study period, essentially similar results were reported for degludec (600 and $900 \mu \mathrm{mol} / \mathrm{L})$ and glargine in terms of change from baseline in $\mathrm{A} 1 \mathrm{C}(-0.6 \%,-0.5 \%$, and $-0.6 \%$, respectively), change from baseline in FPG $(-1.60$, -2.06 , and $-0.54 \mathrm{mmol} / \mathrm{L}$, respectively), and the overall shape of the nine-point self-monitored plasma glucose pro- 
files at end point. Rates of confirmed hypoglycemia and nocturnal hypoglycemia with degludec at 600 and $900 \mu \mathrm{mol} /$ $\mathrm{L}$ were numerically lower compared with glargine.

In insulin-naïve subjects with type 2 diabetes $(n=178)$, once-daily degludec, combined with insulin aspart in two different formulations (70/30 [IDegAsp] and 55/45 [alternative formulation]), was compared with once-daily glargine, administered pre-dinner. ${ }^{95}$ Glycemic control was similar across all treatment groups (i.e., changes from baseline in A1C were $-1.3 \%,-1.5 \%$, and $-1.3 \%$ for IDegAsp, alternative formulation, and glargine, respectively), and approximately $50 \%$ of subjects in all groups achieved A1C $<7.0 \%$. Mean changes from baseline in FPG levels were $-4.3,-4.1$, and $-5.1 \mathrm{mmol} / \mathrm{L}$, respectively, although the 2-h post-dinner plasma glucose increase was lower for both degludec groups than for glargine, which was as expected given the aspart "bolus" component in the degludec treatment arms. The incidence of hypoglycemia and nocturnal hypoglycemia was low and similar across all treatment groups, and increases in body weight were also low and comparable.

The results of a third Phase II randomized trial have also been published comparing once-daily insulin glargine with once-daily ( 600 or $900 \mathrm{nmol} / \mathrm{mL}$ ) or thrice-weekly $(900 \mathrm{nmol} /$ $\mathrm{mL})$ degludec in insulin-naïve individuals with type 2 diabetes. ${ }^{96}$ The data showed comparable improvements in glycemic control and similar, low rates of hypoglycemia across all four treatment groups over 16 weeks of treatment. Changes in body weight were minimal, although a significantly greater change in body weight was observed with once-daily degludec at $900 \mathrm{nmol} / \mathrm{mL}$ compared with insulin glargine. Phase III studies with degludec are ongoing.

Two other basal insulin analogs-LY2605541 and LY2963016-are currently in clinical development. Two Phase II studies that compared LY2605541 with glargine in people with type 1 and type 2 diabetes have been completed (registration numbers NCT01049412 and NCT01027871 at ClinicalTrials.gov), and publication of data is awaited. Phase III clinical testing for both insulins is expected to commence in 2011.

\section{Alternative Approaches Providing Basal Insulin Requirements}

Insulin pumps have been used for several decades in conjunction with a short- or rapid-acting insulin for CSII, particularly in patients with type 1 diabetes, although the practicalities and expense of traditional pump technology may have limited its use. Recent efforts to simplify these delivery systems has resulted in the development of "patch pumps" that integrate an insulin reservoir, delivery system, and cannula into a small, wearable, disposable, or semidisposable device that adheres directly to the skin. ${ }^{97,98}$ In one small-scale, 30-day study of patients with type 1 diabetes, A1C was found to be significantly lower after patients switched from a traditional CSII pump to a patch pump. ${ }^{99}$

A novel approach to injectable therapy currently undergoing preclinical investigation is that of a "glucose-responsive insulin formulation." SmartInsulin ${ }^{\mathrm{TM}}$ (SmartCells Inc., Beverly, MA, USA) consists of a modified insulin that is reversibly bound to an engineered multivalent glucose-binding molecule. ${ }^{100}$ Glucose in the blood competes with the modified insulin to bind to the glucose-binding molecule, thereby displacing the insulin and releasing it into the bloodstream. ${ }^{100}$ Thus, insulin is only released in response to a specific blood glucose concentration, and so, in theory, glucose-responsive insulin formulations may provide basal and prandial insulin requirements with a low risk of hypoglycemia. ${ }^{96}$

\section{Conclusions}

The two currently marketed long-acting insulin analogs, glargine and detemir, represent the most significant advances in "basal insulin" supplementation since the 1940s and 1950s and introduction of the intermediate-acting NPH and lente insulin family, respectively. Both analogs lower the risk for hypoglycemia and nocturnal hypoglycemia, lower FPG, and reduce day-to-day glucose variability, primarily as a result of their pharmacodynamic characteristics. Glargine provides the added benefit of once-daily administration, whereas detemir can be used once or twice daily depending on individual needs. Degludec, which is currently in Phase III clinical development, has the potential to further broaden the options for diabetes treatment with a possible thrice-weekly dosing regimen. It is now essential to construct further large-scale, longer-term clinical studies to compare degludec with glargine to establish whether the new chemical entity offers additional benefits in both efficacy and/or safety in individuals with either type 1 or insulin-requiring type 2 diabetes.

\section{Acknowledgments}

Editorial support for this article was provided by Huw Jones, Ph.D., of Medicus International and was funded by sanofi-aventis.

\section{Author Disclosure Statement}

D.R.O. has acted as a consultant for sanofi-aventis and Roche Diagnostics.

\section{References}

1. Banting FG, Best $\mathrm{CH}$ : The internal secretion of the pancreas. J Lab Clin Med 1922;7:251-266.

2. Banting FG, Best CH, Collip JB, Campbell WR, Fletcher AA: Pancreatic extracts in the treatment of diabetes mellitus. Can Med Assoc J 1922;12:141-146.

3. Burgess N, Campbell JMH, Osman AA, Payne WW, Poulton EP: Early experiences with insulin in the treatment of diabetes mellitus. Lancet 1923;202:777-782.

4. Leyton O: The administration of insulin in suspension. Lancet 1929;213:756-759.

5. Suranyi L, Szalai F: Influence of lipoids on increasing potency of action of insulin. Klin Woch 1930;9:2159.

6. Werner P, Monguio J: Antagonism of insulin and pitutrin. Klin Woch 1933;12:748.

7. Best $\mathrm{CH}$ : The prolongation of insulin action. Ohio J Sci 1937;37:362-377.

8. Dörzbach E, Müller R: Die Insulintherapie: Die Insulinpräparate. In: Handbuch des Diabetes Mellitus II. (Pfeiffer EF, ed.) Munich: Lehmann's Verlag, 1971, 1087-1111.

9. Maxwell LC, Bischoff F: Augmentation of the physiologic response to insulin. Am J Physiol 1935;112:172-175.

10. Scott DA, Fisher AM: The effect of zinc salts on the action of insulin. J Pharmacol Exp Ther 1935;55:206-221.

11. Beecher HK, Krogh A: Microscopic observation of the absorption of insulin and protamine insulinate. Nature 1936;137:458. 
12. Hagedorn HC, Jensen BN, Krarup NB, Wodstrup I: Protamine insulinate. JAMA 1936;106:177-180.

13. Scott DA, Fisher AM: Studies on insulin with protamine. J Pharmacol Exp Ther 1936;58:78-92.

14. Colwell AR: Protamine insulin mixtures in the treatment of diabetes mellitus. N Y State J Med 1947;47:1103-1110.

15. Himsworth HP: Protamine insulin and zinc protamine insulin. BMJ 1937;1:541-546.

16. Colwell AR, Izzo JL, Stryker WA: Intermediate action of mixtures of soluble insulin and protamine zinc insulin. Arch Intern Med 1942;69:931-951.

17. Campbell WR, Fletcher AA, Kerr RB: Protamine insulin in the treatment of diabetes mellitus. Am J Med Sci 1936; 192:589-600.

18. Lawrence RD, Archer N: Zinc protamine insulin. BMJ 1937;1:487-491.

19. Peck FB, Schechter JS: The new insulin mixtures-a followup study. Proc Am Diabetes Assoc 1944;4:59-80.

20. Krayenbuhl C, Rosenberg T: Crystalline protamine insulin. Rep Steno Mem Hosp Nord Insulinlab 1946;1:60-73.

21. Oakley W, Hill D, Oakley N: Combined use of regular and crystalline protamine (NPH) insulins in the treatment of severe diabetes. Diabetes 1966;15:219-222.

22. Bauman L: Clinical experience with globin insulin. Am J Med Sci 1939;198:475-481.

23. Reiner L, Searle DS, Lang EH: On the hypoglycemic activity of globin insulin. J Pharmacol Exp Ther 1939;67:330-340.

24. Umber F, Stoerring FK, Foellmer W: Erfolge mit einem neuartigen Depot Insulin ohne Protaminzusatz (SurfenInsulin). Klin Woch 1938;17:443-446.

25. Hallas-Mǿller K: The lente insulins. Diabetes 1956;5:7-14.

26. Whitehouse FW, Lowrie WL, Redfern E, Bryan JB: The lente insulin triad, with emphasis on the use of "lente combinations." Ann Intern Med 1961;55:894-902.

27. Galloway JA, Bressler R: Insulin treatment in diabetes. Med Clin North Am 1978;62:663-680.

28. Schlichtkrull J: In: Diabetes Mellitus III. Kongress der International Diabetes Federation Düsseldorf (Oberdisse K, Jahnke K, eds.). Stuttgart: Georg Thieme, 1959:773-777.

29. Schlichtkrull J, Funder J, Munck O: Clinical evaluation of a new insulin preparation. In: 4e Congrès de la Féderation Internationale du Diabète, Genève (Demole, ed.). Geneva: Editions Médecine et Hygiène, 1961:303-305.

30. Schlichtkrull J, Munck O, Jersild M: Insulin Rapitard and insulin Actrapid. Acta Med Scand 1965;177:103-113.

31. Markussen J, Damgaard U, Jorgensen KH, Sorensen E, Thim L: Human monocomponent insulin. Chemistry and characteristics. Acta Med Scand Suppl 1983;671:99-105.

32. Thim L, Hansen MT, Sorensen AR: Secretion of human insulin by a transformed yeast cell. FEBS Lett 1987;212:307-312.

33. Garber AJ, Davidson JA, Krosnick A, Beaser RS, Anderson JH Jr: Impact of transfer from animal-source insulins to biosynthetic human insulin (rDNA $E$ coli) in patients with diabetes mellitus. Clin Ther 1991;13:627-636.

34. Hildebrandt P, Birch K, Sestoft L, Volund A: Human Monotard insulin: dose-dependent subcutaneous absorption. Diabetes Res 1984;1:183-185.

35. Owens DR, Vora JP, Heding LG, Luzio S, Ryder RE, Atiea J, Hayes TM: Human, porcine and bovine ultralente insulin: subcutaneous administration in normal man. Diabet Med 1986;3:326-329.

36. Galloway JA, Hooper SA, Spradlin CT, Howey DC, Frank $\mathrm{BH}$, Bowsher RR, Anderson JH: Biosynthetic human proinsulin. Review of chemistry, in vitro and in vivo receptor binding, animal and human pharmacology studies, and clinical trial experience. Diabetes Care 1992;15:666-692.

37. Shojaee-Moradie F, Powrie JK, Sundermann E, Spring MW, Schuttler A, Sonksen PH, Brandenburg D, Jones RH: Novel hepatoselective insulin analog: studies with a covalently linked thyroxyl-insulin complex in humans. Diabetes Care 2000;23:1124-1129.

38. Markussen J, Diers I, Hougaard P, Langkjaer L, Norris K, Snel L, Sorensen AR, Sorensen E, Voigt HO: Soluble, prolonged-acting insulin derivatives. III. Degree of protraction, crystallizability and chemical stability of insulins substituted in positions A21, B13, B23, B27 and B30. Protein Eng 1988;2:157-166.

39. Markussen J, Hougaard P, Ribel U, Sorensen AR, Sorensen E: Soluble, prolonged-acting insulin derivatives. I. Degree of protraction and crystallizability of insulins substituted in the termini of the B-chain. Protein Eng 1987;1:205-213.

40. Jorgensen S, Vaag A, Langkjaer L, Hougaard P, Markussen J: NovoSol Basal: pharmacokinetics of a novel soluble long acting insulin analogue. BMJ 1989;299:415-419.

41. Holman R, Steemson J: OPID 174: a novel long-acting insulin preparation [abstract]. Diabet Med 1989;6:A41.

42. Rosskamp RH, Park G: Long-acting insulin analogs. Diabetes Care 1999;22(Suppl 2):B109-B113.

43. Berchtold H, Hilgenfeld R: Binding of phenol to R6 insulin hexamers. Biopolymers 1999;51:165-172.

44. Bolli GB, Di Marchi RD, Park GD, Pramming S, Koivisto VA: Insulin analogues and their potential in the management of diabetes mellitus. Diabetologia 1999;42:1151-1167.

45. Marshall SA, Lazar GA, Chirino AJ, Desjarlais JR: Rational design and engineering of therapeutic proteins. Drug Discov Today 2003;8:212-221.

46. Kuerzel GU, Shukla U, Scholtz HE, Pretorius SG, Wessels $\mathrm{DH}$, Venter C, Potgieter MA, Lang AM, Koose T, Bernhardt E: Biotransformation of insulin glargine after subcutaneous injection in healthy subjects. Curr Med Res Opin 2003;19: 34-40.

47. Heise T, Bott S, Rave K, Dressler A, Rosskamp R, Heinemann L: No evidence for accumulation of insulin glargine (LANTUS): a multiple injection study in patients with Type 1 diabetes. Diabet Med 2002;19:490-495.

48. Porcellati F, Rossetti P, Ricci NB, Pampanelli S, Torlone E, Campos SH, Andreoli AM, Bolli GB, Fanelli CG: Pharmacokinetics and pharmacodynamics of the long-acting insulin analog glargine after 1 week of use compared with its first administration in subjects with type 1 diabetes. Diabetes Care 2007;30:1261-1263.

49. Lepore M, Pampanelli S, Fanelli C, Porcellati F, Bartocci L, Di Vincenzo A, Cordoni C, Costa E, Brunetti P, Bolli GB: Pharmacokinetics and pharmacodynamics of subcutaneous injection of long-acting human insulin analog glargine, $\mathrm{NPH}$ insulin, and ultralente human insulin and continuous subcutaneous infusion of insulin lispro. Diabetes 2000;49: 2142-2148.

50. Porcellati F, Rossetti P, Busciantella NR, Marzotti S, Lucidi P, Luzio S, Owens DR, Bolli GB, Fanelli CG: Comparison of pharmacokinetics and dynamics of the long-acting insulin analogs glargine and detemir at steady state in type 1 diabetes: a double-blind, randomized, crossover study. Diabetes Care 2007;30:2447-2452.

51. Becker RH, Frick AD, Burger F, Potgieter JH, Scholtz H: Insulin glulisine, a new rapid-acting insulin analogue, displays a rapid time-action profile in obese non-diabetic subjects. Exp Clin Endocrinol Diabetes 2005;113:435-43. 
52. Heinemann L, Linkeschova R, Rave K, Hompesch B, Sedlak $\mathrm{M}$, Heise T: Time-action profile of the long-acting insulin analog insulin glargine (HOE901) in comparison with those of NPH insulin and placebo. Diabetes Care 2000;23: 644-649.

53. Heise T, Nosek L, Ronn BB, Endahl L, Heinemann L, Kapitza C, Draeger E: Lower within-subject variability of insulin detemir in comparison to $\mathrm{NPH}$ insulin and insulin glargine in people with type 1 diabetes. Diabetes 2004; 53:1614-1620.

54. Klein O, Lynge J, Endahl L, Damholt B, Nosek L, Heise T: Albumin-bound basal insulin analogues (insulin detemir and NN344): comparable time-action profiles but less variability than insulin glargine in type 2 diabetes. Diabetes Obes Metab 2007;9:290-299.

55. Gerich J, Becker RH, Zhu R, Bolli GB: Fluctuation of serum basal insulin levels following single and multiple dosing of insulin glargine. Diabetes Technol Ther 2006;8:237-243.

56. Scholtz HE, Pretorius SG, Wessels DH, Becker RH: Pharmacokinetic and glucodynamic variability: assessment of insulin glargine, NPH insulin and insulin ultralente in healthy volunteers using a euglycaemic clamp technique. Diabetologia 2005;48:1988-1995.

57. Kudva YC, Basu A, Jenkins GD, Pons GM, Vogelsang DA, Rizza RA, Smith SA, Isley WL: Glycemic variation and hypoglycemia in patients with well-controlled type 1 diabetes on a multiple daily insulin injection program with use of glargine and ultralente as basal insulin. Endocr Pract 2007;13:244-250.

58. Bruttomesso D, Crazzolara D, Maran A, Costa S, Dal Pos M, Girelli A, Lepore G, Aragona M, Iori E, Valentini U, Del Prato S, Tiengo A, Buhr A, Trevisan R, Baritussio A: In Type 1 diabetic patients with good glycaemic control, blood glucose variability is lower during continuous subcutaneous insulin infusion than during multiple daily injections with insulin glargine. Diabet Med 2008;25:326-332.

59. Lepore G, Dodesini AR, Nosari I, Trevisan R: Effect of continuous subcutaneous insulin infusion vs multiple daily insulin injection with glargine as basal insulin: an open parallel long-term study. Diabetes Nutr Metab 2004; 17:84-89.

60. Garg SK, Walker AJ, Hoff HK, D'Souza AO, Gottlieb PA, Chase HP: Glycemic parameters with multiple daily injections using insulin glargine versus insulin pump. Diabetes Technol Ther 2004;6:9-15.

61. Bolli GB, Capani F, Home PD, Kerr D, Thomas R, Torlone E, Selam JL, Sola-Gazagnes A, Vitacolonna E: Comparison of a multiple daily injection regimen with once-daily insulin glargine basal insulin and mealtime lispro, to continuous subcutaneous insulin infusion: a randomised, open, parallel study [abstract]. Diabetes 2004;53:A107.

62. Bolli GB, Kerr D, Thomas R, Torlone E, Sola-Gazagnes A, Vitacolonna E, Selam JL, Home PD: Comparison of a multiple daily insulin injection regimen (basal once-daily glargine plus mealtime lispro) and continuous subcutaneous insulin infusion (lispro) in type 1 diabetes: a randomized open parallel multicenter study. Diabetes Care 2009; 32:1170-1176.

63. Kurtzhals P, Schaffer L, Sorensen A, Kristensen C, Jonassen I, Schmid C, Trub T: Correlations of receptor binding and metabolic and mitogenic potencies of insulin analogs designed for clinical use. Diabetes 2000;49:999-1005.

64. Hansen BF, Danielsen GM, Drejer K, Sorensen AR, Wiberg FC, Klein HH, Lundemose AG: Sustained signalling from the insulin receptor after stimulation with insulin analogues exhibiting increased mitogenic potency. Biochem J 1996;315:271-279.

65. Davis MD, Beck RW, Home PD, Sandow J, Ferris FL: Early retinopathy progression in four randomized trials comparing insulin glargine and NPH [corrected] insulin. Exp Clin Endocrinol Diabetes 2007;115:240-243.

66. Rosenstock J, Fonseca V, McGill JB, Riddle M, Halle JP, Hramiak I, Johnston P, Davis M: Similar progression of diabetic retinopathy with insulin glargine and neutral protamine Hagedorn (NPH) insulin in patients with type 2 diabetes: a long-term, randomised, open-label study. Diabetologia 2009;52:1778-1788.

67. Ashwell SG, Gebbie J, Home PD: Optimal timing of injection of once-daily insulin glargine in people with Type 1 diabetes using insulin lispro at meal-times. Diabet Med 2006;23:46-52.

68. Mucha GT, Merkel S, Thomas W, Bantle JP: Fasting and insulin glargine in individuals with type 1 diabetes. Diabetes Care 2004;27:1209-1210.

69. Peter R, Luzio SD, Dunseath G, Miles A, Hare B, Backx K, Pauvaday V, Owens DR: Effects of exercise on the absorption of insulin glargine in patients with type 1 diabetes. Diabetes Care 2005;28:560-565.

70. Riddle MC, Rosenstock J, Gerich J: The treat-to-target trial: randomized addition of glargine or human NPH insulin to oral therapy of type 2 diabetic patients. Diabetes Care 2003;26:3080-3086.

71. Mullins P, Sharplin P, Yki-Jarvinen H, Riddle MC, Haring $\mathrm{HU}$ : Negative binomial meta-regression analysis of combined glycosylated hemoglobin and hypoglycemia outcomes across eleven Phase III and IV studies of insulin glargine compared with neutral protamine Hagedorn insulin in type 1 and type 2 diabetes mellitus. Clin Ther 2007;29:1607-1619.

72. Barlocco D: Insulin detemir. Novo Nordisk. Curr Opin Investig Drugs 2003;4:449-454.

73. Havelund S, Plum A, Ribel U, Jonassen I, Volund A, Markussen J, Kurtzhals P: The mechanism of protraction of insulin detemir, a long-acting, acylated analog of human insulin. Pharm Res 2004;21:1498-1504.

74. Kragh-Hansen U: Structure and ligand binding properties of human serum albumin. Dan Med Bull 1990;37:57-84.

75. Peters T Jr: Serum albumin. Adv Protein Chem 1985;37: 161-245.

76. Kurtzhals P, Havelund S, Jonassen I, Kiehr B, Larsen UD, Ribel U, Markussen J: Albumin binding of insulins acylated with fatty acids: characterization of the ligand-protein interaction and correlation between binding affinity and timing of the insulin effect in vivo. Biochem J 1995;312:725731.

77. Rowland M, Tozer TM: Clinical Pharmacokinetics. Bethesda, MD: American Physiological Society, 1989.

78. Kurtzhals P: Engineering predictability and protraction in a basal insulin analogue: the pharmacology of insulin detemir. Int J Obes Relat Metab Disord 2004;28(Suppl 2):S23S28.

79. Hamilton-Wessler M, Ader M, Dea MK, Moore D, Loftager M, Markussen J, Bergman RN: Mode of transcapillary transport of insulin and insulin analog NN304 in dog hindlimb: evidence for passive diffusion. Diabetes 2002;51: 574-582.

80. Hordern SV, Wright JE, Umpleby AM, Shojaee-Moradie F, Amiss J, Russell-Jones DL: Comparison of the effects on 
glucose and lipid metabolism of equipotent doses of insulin detemir and NPH insulin with a 16-h euglycaemic clamp. Diabetologia 2005;48:420-426.

81. Rossetti P, Porcellati F, Ricci NB, Candeloro P, Cioli P, Bolli GB, Fanelli CG: Different brain responses to hypoglycemia induced by equipotent doses of the long-acting insulin analog detemir and human regular insulin in humans. Diabetes 2008;57:746-756.

82. Radziuk J, Pye S, Bradley B, Braaten J, Vignati L, Roach P, Bowsher R, DiMarchi R, Chance R: Basal activity profiles of $\mathrm{NPH}$ and [Nepsilon-palmitoyl Lys (B29)] human insulins in subjects with IDDM. Diabetologia 1998;41:116-120.

83. Hermansen K, Davies M, Derezinski T, Martinez Ravn G, Clauson P, Home P: A 26-week, randomized, parallel, treat-to-target trial comparing insulin detemir with $\mathrm{NPH}$ insulin as add-on therapy to oral glucose-lowering drugs in insulin-naive people with type 2 diabetes. Diabetes Care 2006;29:1269-1274.

84. Rosenstock J, Davies M, Home PD, Larsen J, Koenen C, Schernthaner G: A randomised, 52-week, treat-to-target trial comparing insulin detemir with insulin glargine when administered as add-on to glucose-lowering drugs in insulin-naive people with type 2 diabetes. Diabetologia 2008;51:408-416.

85. Home P, Kurtzhals P: Insulin detemir: from concept to clinical experience. Expert Opin Pharmacother 2006;7: 325-343.

86. Swinnen SG, Dain MP, Aronson R, Davies M, Gerstein HC, Pfeiffer AF, Snoek FJ, Devries JH, Hoekstra JB, Holleman F: A 24-week, randomized, treat-to-target trial comparing initiation of insulin glargine once-daily with insulin detemir twice-daily in patients with type 2 diabetes inadequately controlled on oral glucose-lowering drugs. Diabetes Care 2010;33:1176-1178.

87. Hollander P, Cooper J, Bregnhoj J, Pedersen CB: A 52-week, multinational, open-label, parallel-group, noninferiority, treat-to-target trial comparing insulin detemir with insulin glargine in a basal-bolus regimen with mealtime insulin aspart in patients with type 2 diabetes. Clin Ther 2008; 30:1976-1987.

88. Raskin P, Gylvin T, Weng W, Chaykin L: Comparison of insulin detemir and insulin glargine using a basal-bolus regimen in a randomized, controlled clinical study in patients with type 2 diabetes. Diabetes Metab Res Rev 2009; 25:542-548.

89. Dailey G, Admane K, Mercier F, Owens D: Relationship of insulin dose, A1c lowering, and weight in type 2 diabetes: comparing insulin glargine and insulin detemir. Diabetes Technol Ther 2011;12:1019-1027.

90. Zinman B, Fulcher G, Rao PV, Thomas N, Endahl L, Johansen T, Lewin A, Rosenstock J, Pinget M, Mathieu C: Insulin degludec, a new generation ultra-long acting insulin, used once daily or 3-times weekly in people with Type 2 diabetes: comparison to insulin glargine [abstract]. Diabetes 2010;59:A40-OR.

91. Mathieu C, Fulcher G, Rao PV, Thomas L, Endahl L, Johansen T, Lewin AJ, Rosenstock J, Pinget M, Zinman B:
Insulin degludec, a new generation ultra-long acting insulin, used once daily or 3-times weekly in people with type 2 diabetes: comparison to insulin glargine [abstract]. Diabetologia 2010;53:A4.

92. Jonassen IB, Havelund S, Ribel U, Hoeg-Jensen T, Steensgaard DB, Johansen T, Haahr H, Nishimura E, Kurtzhals P: Insulin degludec is a new generation ultra-long acting basal insulin with a unique mechanism of protraction based on multihexamer formation [abstract]. Diabetes 2010;59:A39-OR.

93. Jonassen I, Havelund S, Ribel U, Hoeg-Jensen T, Steensgaard DB, Johansen T, Haahr H, Nishimura E, Kurtzhals P: Insulin degludec: multi-hexamer formation is the underlying basis for this new generation ultra-long acting basal insulin [abstract]. Diabetologia 2010;53:A972.

94. Birkeland KI, Home PD, Wendisch U, Ratner RE, Johansen T, Endahl LA, Lyby K, Jendle JH, Roberts AP, DeVries JH, Meneghini LF: Insulin degludec in type 1 diabetes: a randomized controlled trial of a new-generation ultra-longacting insulin compared with insulin glargine. Diabetes Care 2011;34:661-665.

95. Heise T, Tack CJ, Cuddihy R, Davidson J, Gouet D, Liebl A, Romero E, Mersebach H, Dykiel P, Jorde R: A newgeneration ultra-long-acting basal insulin with a bolus boost compared with insulin glargine in insulin-naive people with type 2 diabetes: a randomized, controlled trial. Diabetes Care 2011;34:669-674.

96. Zinman B, Fulcher G, Rao PV, Thomas N, Endahl LA, Johansen $T$, Lindh R, Lewin A, Rosenstock J, Pinget $M$, Mathieu C: Insulin degludec, an ultra-long-acting basal insulin, once a day or three times a week versus insulin glargine once a day in patients with type 2 diabetes: a 16week, randomised, open-label, phase 2 trial. Lancet 2011; 377:924-931.

97. Anhalt H, Bohannon NJ: Insulin patch pumps: their development and future in closed-loop systems. Diabetes Technol Ther 2010;12(Suppl 1):S51-S58.

98. Skladany MJ, Miller M, Guthermann JS, Ludwig CR: Patchpump technology to manage type 2 diabetes mellitus: hurdles to market acceptance. J Diabetes Sci Technol 2008; 2:1147-1150.

99. Zisser H, Jovanovic L: OmniPod Insulin Management System: patient perceptions, preference, and glycemic control. Diabetes Care 2006;29:2175.

100. Chu J: Smart Insulin: An Experimental Drug for Diabetes Dispenses Insulin in Response to Glucose Levels. Technology Review 2008. www.technologyreview.com/ biomedicine/21613/ (accessed May 2, 2011).

Address correspondence to: David R. Owens, C.B.E., M.D., FRCP, FIBiol Diabetes Research Unit Cardiff University University Hospital Llandough Penarth, UK

E-mail: owensdr@cf.ac.uk 